- Cheng, M. (2017 online). Reclaiming Quality in Higher Education: A Human Factor Approach. Quality in Higher Education, 23(3) http://www.tandfonline.com/eprint/iQwIKumMa6pIedCiKFUu/full

\title{
Reclaiming Quality in Higher Education: A Human Factor Approach Ming Cheng
}

\begin{abstract}
Interest in quality is well established within higher education. This paper will critically review the most commonly used definitions of quality: fitness for purpose and value for money. It will point out that these two definitions are important but they ignore the emancipatory power of higher education and the development needs of academics and students. This paper will propose a new understanding of quality as a virtue of professional practice, which can be used as a useful force for individual academics and students to increase their commitment to learning and teaching. A new model of quality evaluation will be outlined as a supportive mechanism to enhance academics' professionalism and to increase students' capability to learn.
\end{abstract}

Key words: quality, capability, professionalism, fitness for purpose, value for money, higher education

\section{Introduction}


Quality is a key word in higher education. There are different interpretations of quality and its evaluation methods. The most commonly cited definitions are proposed by Harvey and Green (1993) and quality is interpreted as exception, perfection, fitness for purpose, value for money and transformation. These conceptions offer different analytical frameworks to consider the meaning of quality in higher education (Lomas, 2002). This paper will critically analyse the two most widely used definitions of quality: fitness for purpose and value for money. It will then propose a new understanding of quality as a virtue of professional practice, which define quality in terms of its value for promoting stakeholders' intrinsic excellence and motivation in wanting to learn and to teach in a professional way. In other words, quality can be achieved through enhancing academics' professionalism and students' capability to learn. At the end of this paper, a new model of quality evaluation will be outlined to develop such a virtue of professional learning in the higher education sector.

\section{Fitness for purpose}

Fitness for purpose has become the most widely adopted approach to evaluate quality in higher education (Woodhouse, 1996; Wicks \& Roethlein, 2009). Its origins can be dated back to the Total Quality Management philosophy in industry (Harvey \& Williams, 2010). It emphasises the establishment of national and institutional structures for evaluating quality (Schwarz \& Westerheijden, 2004), and it takes on the practice of assuring structural, organisational and managerial processes within institutions (Westerheijden et al., 2007). Quality as fitness for purpose, in this sense, can be understood as systems and process control. 
Fitness for purpose aims for management by objectives. It allows institutions to define their purposes in their mission and objectives; and quality is demonstrated by achieving these. However, it can be difficult to assess the objectives with either a qualitative or quantitative measure, as the objectives may not be stated clearly or implied easily. Furthermore, the focus on institutional missions does not evaluate the quality of the educational process and its outcomes but strengthens external influences on the performance of the institution (Dill, 2001). This ignores that there is a fundamental difference between the actual practice of teaching and learning and the current ways in which institutions are evaluated for their performance (Haggis, 2009).

\section{An analysis of the purpose}

Purpose is a key component in the definition of quality as fitness for purpose but there is no agreement on what purpose and for whose purpose. One view is that the purpose is to meet the needs of students and employers as customers. This is evidenced in the 2003 White Paper The Future of Higher Education (DfES, 2003) and the 2016 White Paper Teaching Excellence, Social Mobility and Student Choice (BIS, 2016) that makes quality become a means for customer satisfaction and to achieve better value for money and employment prospects for students. This user-based definition makes quality individual and subjective, as the expectations of customers can vary. It contradicts the current practice of quality evaluation, which checks institutional performance instead of individual student's learning experience. 
Another view is that purpose is often associated with the government's political ambitions of changing the way institutions work in a more competitive and economical way. It aims for short-term benefit, and has created concerns in the higher education sector, including compliance to pre-determined indicators without considering the diversity of learning and teaching (Skolnik, 2010), the gap between academics' and students' understandings of quality (Cheng, 2012), and the emerging consumer culture that focuses on meeting students' needs instead of teaching students how to learn (Molesworth et al., 2009).

The pragmatic approach of fitness for purpose does not consider the people-building purpose of higher education. It ignores the inspirational philosophy developed in industry that quality is more than management and is people-oriented (Crosby, 1979). This philosophy means that people need to be empowered, professionalised and given the opportunity to tackle the problems they recognise and have the skills to solve them (Hutchins, 1992). The overemphasis on quality for management purposes causes insecurity and distrust among academics who are the most precious resource in the higher education sector. According to Deming's theory of management, fear results in loss (Drummond, 1992). This means that fear will force individual institutions and academics to concentrate upon satisfying rules of quality evaluation, treating it as a box-ticking exercise, at the expense of making a real contribution to the improvement of learning and teaching.

Cheng's (2009) research on the quality audit culture in England suggested that there is a tension between academics' notion of professionalism and the requirements of quality assurance and that academics feel that quality assurance is detached from their individual 
academic work. This implies that if the quality imperative is based on pressure from the market and from the Government, it will not be recognised as an inner need for improvement by academics.

\section{Value for money}

The notion of value for money is another popular view of quality in higher education, and it was first presented by the 1984 Audit Commission (Watty, 2003). It associates quality with expense and economic exchange, and originally means that customers are willing to pay for better quality, and what pleases a customer most is superior quality for the same money or less money (Drummond, 1992).

The notion of accountability is central to the definition of quality as value for money. It is closely related to the 'neoliberal ideology' that education should contribute to a country's industrial development and that the relationship between students and their institutions or teachers becomes defined in economic terms (Saunders, 2010, 2011). This is because neoliberalism redefines individuals as consumers who use a cost-benefit analysis to make all of their decisions (Giroux, 2005; Saunders \& Ramirez, 2016). However, there is a concern that a neoliberal university is strongly associated with an economic rather than a cultural imperative, which makes its internationalisation degenerate into instrumentalism (Harris, 2008).

\section{The customer orientation}


Quality as value for money is closely related to a notion of student as customer. One observation is that tuition fees have shifted student expectation of, and attitudes towards, higher education, although some European countries, for example, Germany, have not taken up the fee systems. Students perceive themselves as customers purchasing a product (George, 2007; Tomlinson, 2016). This suggests the application of free-market logic to the relationship between students and the institution or academics. The change of students' attitudes and expectation of higher education has manifested in increased focus on grades, the priority of financial outcomes over educational outcomes (Clayson \& Haley, 2005), the emphasis on customer service (Titus, 2008), and the provision of training for students' employability (Sharrock, 2000; Lusk \& Fearful, 2014).

There are debates on the notion of student as customer. One view is that the concept of customer-defined quality is problematic (Eagle \& Brennan, 2007; Houston, 2008), as this conception will lead to a passive approach to education (Saunders, 2011). This is because improvement can only be achieved through increasing students' effort in learning. Another view is that students do not fit the traditional model of customers in that customers are free to purchase products that they want, whereas students' freedom of choice is limited. They need to satisfy the university entry criteria before they can 'purchase' an educational 'product' (George, 2007). Students cannot simply purchase their degrees, because they need to pass designated examinations in order to obtain their degrees (Delucchi \& Korgen, 2002; George, 2007). Furthermore, there is conflict in the perceived role of academics as subject experts and their perceived role of providing a purchased product to a student, as students lack the 
experience to understand the subject fields that they choose to study (Redding, 2005). This differs from the customer-related truism that 'the customers know what they want' (Winston, 1999; Biesta, 2015).

This customer model also compartmentalises the educational experience as a product, as opposed to a process (McMillan \& Cheney, 1996). This could lead to a gap between how academics and students expect and understand quality. For example, Cheng (2011) revealed that academics tend to associate quality with students' learning experience but students are pragmatic and relate quality to academic teaching practice and its impact on their learning outcomes. This gap implies that if educational experience is treated as a product, it may encourage the view that students need 'spoon-feeding' from academics, as they have paid for the education. Academics, therefore, need to clarify that students should take an active role in the learning process.

Williams (2012) provided an historical analysis of the notion of consumerism and pointed out that it is fundamentally disconnected from intellectual engagement. Cheng et al. (2016) held similar concerns that the demand to produce satisfied consumers may force lecturers to avoid making intellectual challenges of their students and instead teach to provide entertainment. This indicates that the notion of students as customers downplays students' responsibility in learning, and it does not consider the continuous improvement purpose of higher education. This would result in unresolved tension between the purpose of control and the purpose of improvement in learning (Brown, 2014). 
It is worth noting that students could have multifaceted understandings of quality. For example, Jungblut et al.'s (2015) study revealed that students not only perceive themselves as customers but also prefer perspectives that they are in the centre of the quality process, though not necessarily only as active participants. These perspectives suggest that there is a need for higher education institutions to manage student expectations and to put appropriate mechanisms in place to handle this consumerist culture (Jones, 2010).

\section{Quality as a virtue of professional practice}

Clearly, both notions of fitness for purpose and value for money relate quality to the input and accountability from academics and higher education institutions. They emphasise institutional

performance and judgement by external quality agencies, and performance is related to an institution's proficiency in having quality mechanisms in place. This approach reflects a 'passive' view of quality, ignoring that learning is an individual activity and that students' commitment in learning is as important as the input from academics and the university.

Based on the findings of five completed research projects, this article argues that relating quality mainly to management purposes ignores the development needs of academics and students. These five projects explored the conceptions of quality, and the practice of quality evaluation and its impact on the work of academics and student learning experience, from the perspectives of over 200 academics and students in the United Kingdom (UK). These academics and students were from different subject areas in four universities. One of the 
universities is world-renowned, another two universities are research intensive, and the fourth university is a post-1992 university, which is teaching intensive.

This paper reclaims the idea of quality from a purely managerialist approach. It interprets quality as a virtue of professional practice, which can be achieved through developing students' capability to learn, rebuilding trust in academic professionalism and improving quality evaluation systems to increase academics' and students' commitment to teaching and learning. Virtue here refers to a persisting excellence in being for the good (Adams 2006). In other words, virtues are forms of love to teaching and learning, not simply of compliance to pre-determined standards and criteria.

Quality as a virtue of professional practice involves stakeholders' self-motivation to do well in their job, and to enjoy the state of being an academic or a student. This involves a perspective in what matters most to key stakeholders of higher education and what kind of students and academics to become in the process of teaching and learning.

To say that quality is a virtue of professional practice is to insist that quality is one of the things that enable stakeholders to value higher education and to actively engage with that to make learning enjoyable. It is reflective in the sense that it enables academics and students to know what they want to achieve, what they have achieved, how they achieved that, and whether there is any scope to do better. Developing quality as a virtue of professional practice encourages a culture for stakeholders to self-evaluate their teaching/learning practices and to improve upon that. 
Quality as a virtue of professional practice depends largely on the value of what academics and students work for and what they want to achieve from university education. It is beneficial to those who pursue it, as Socrates, Plato and the Stoics held that the nature of virtue makes its possessor a happy or flourishing person. In higher education, quality as a virtue of professional practice will make academics and students develop their confidence and self-knowledge of who they are, what they aim to achieve, and how they should act towards this. The sections below will illustrate how quality as a virtue of professional practice can be achieved through developing students' capability to learn and rebuilding trust towards academics' professionalism.

\section{Capability to learn}

Capabilities here refer to an individual's beliefs, thoughts and personal disposition (Nussbaum, 2000). The paper acknowledges that the concept of capability is proposed by Sen (1992, 1999) and developed by Nussbaum $(2000,2006)$. It is based on the notion of opportunity freedom, which emphasises the 'functionings' of individuals to 'be' and 'do': 'to choose the lives they have reasons to value' (Sen, 1992, p. 81). This means that each person should be seen as a 'source of agency and worth in their own right, with their own plans to make and their own lives to live' (Nussbaum, 2000, p. 58). In these terms, what students choose to value in and through learning ought to contribute substantially to the quality of university education, improving their own lives and the lives of others after their graduation. 
This paper points out that the current quality evaluation mechanisms have encouraged the measurement of student performance as an end product, ignoring the process that students need to follow to become engaged with learning in order to achieve good learning outcomes. The focus on the assessment of designated knowledge and skills and the measurement of performance ignores that the fluid nature of the student mindset may affect their academic performance unpredictably. This, together with the view of students as customers, has encouraged the practice of universities needing to provide better service to please students, which will compromise student learning in what to learn, how to learn, and limit their opportunities to fulfill their potential.

There is a need to develop student capabilities to let them comprehend the role they play in achieving successful learning, as the degree of student engagement and the mindset they bring to the educational setting are critical to the quality of their education. There is good evidence in Sideridis (2001) that students' perceptions about the importance of learning affects their intentions and efforts towards achieving learning goals. Students' capability building is, therefore, important, as it improves individual student's academic performance; and it encourages students to reflect on their learning and their personal knowledge and skills to enable them to make choices based on those values. It also enables academic staff to look beneath learning outcomes to find out how to increase student personal effort in learning and what to opportunities and support to offer students to meet their expectations of university education. 


\section{Academic professionalism}

Rebuilding trust to academics' professionalism is another key to achieving quality in higher education. The traditional view of professionalism is often associated with five key principles: the possession of specialist knowledge and expertise, autonomy in professional practice, ritualised entry, probity and integrity (Johnson, 1973; Eraut, 1994; Larson, 1977; Freidson, 2001). These principles suggest a sense of power, status, exclusion and occupational control. There is a shift towards egalitarian understandings of professionalism nowadays, which implies that professionalism applies to every occupational workforce (Noordegraaf, 2007; Evetts, 2013).

Academic professionalism has been widely discussed under two main themes: the new professionalism discourse and discourses related to managerialism (Sachs, 2003; Evetts, 2009). Goodson (1999) proposes principles for new professionalism as: the cognitive dimensions of knowledge, the moral, social, and emotional dimensions of teaching. Sachs (2003) termed the new professionalism as 'transformative' and 'activist' professionalism, whereas Evetts (2009) labelled it 'occupational' professionalism.

The discourse of professionalism related to managerialism has created a lot of concerns. One view is that professional values are replaced by organisational values, because this professionalism involves competencies and licensing rather than trust, accompanied by standardisation of work practices, performance targets, and accountability, rather than professional judgement (Evetts, 2009). Winch and Foreman-Peck (2005) held a similar view that the regulatory standards, which are not set by the profession, lead to compliance 
professionalism, and that academics' professional expertise is reduced to classroom management and the technical aspects of teaching. These concerns suggest that current quality evaluation focuses on the measurement of academics' accountability and teaching

performances but provides limited support to enhance their professionalism to pursue their core values in their profession.

\section{Moral dimensions of academic professionalism}

Management and measurement are important but not at the cost of human factors. The current quality evaluation has aggravated these challenges by its instrumental interest, ignoring that it is the moral content of academic professionalism, such as confidence and intrinsic values, which largely determines the performance of academics at work.

Research reveals that there are increasing challenges for academics to work, to survive and to thrive as professionals (Anderson, 2006; McAlpine, 2010; Ren \& Caudle, 2016). There are growing concerns about the stress associated with academic work, loss of professional identity and decreased job satisfaction (Mikkelsen et al., 2005; Anderson, 2006). Despite the pressure to demonstrate high-level performance in teaching and research, academics are now expected to get closely involved with administrative tasks and to actively interact with industry and the community to build collaborative partnerships. Academics' increasing engagement with industry and the community is seen as an important way to strengthen a university's contribution to economic and social outcomes (Bolden \& Petrov, 2008; Saltmarsh, 2016). However, the overemphasis on academics' duties restrains academics' 
professional development by reducing their opportunities to develop subject expertise, especially when they are under pressure to become know-all to respond to market needs and to meet managerial demands.

With the influence of quality evaluation, academics are further scrutinised for their effectiveness and efficiency in performing their roles. This over-management comes at a significant human cost and has resulted in low morale within the academic workforce, particularly for those with a strong sense of professional identity (Winter et al., 2000; Bowen et al., 2016). For example, quality evaluation increases the pressure for academic staff to comply with enacted standards and criteria in order to succeed in teaching measures, while ignoring that academic work has emotional aspects. Studies show that the academic workplace is an emotionally charged environment, invested with different feelings and emotions, which affect academic performance (Ehn \& Löfgren, 2009). When academics are constantly judged and evaluated for their performance, this creates a difficult working environment (Ehn \& Löfgren, 2009). This may affect academics' perception of the importance of teaching, their intellectual commitment to teaching, and their willingness to motivate students to learn (Dipardo \& Potter, 2004).

What attract academics to the profession and what they value most is the intellectual stimulation and passion for their subjects (Meyer \& Evans, 2003; Tipples, Krivokapic-Skoko, \& O'Neill, 2007; Arkoudis et al., 2012). Academics are known as committed to their profession (Houston et al., 2006). Professional work gives them identity, self-actualisation 
and social image (Al-Rubaish et al., 2011). When management challenge academics' values, academics become demotivated.

The focus on human factors could develop the academic workforce, as people are the university's most precious resource. Quality evaluation has increased the feeling of distrust of academics, which may endanger academics' moral integrity and their confidence in their subject expertise. As MacIntyre (2007) argued, the public will lose confidence in a profession if its moral dilemmas appear to be insoluble. In the context of higher education, the academic profession needs to reach a solution on the challenges they are facing when fulfilling the duty of their profession to society. They need to clarify academics' roles in supporting students to learn, and ask for space for academics' professional development and the enhancement of subject expertise.

Academics need to be encouraged to increase their confidence in what they do. Motivated academics are essential to the survival and development of the university (Capelleras, 2005; Houston et al., 2006). Management tools may not work until academics are motivated, because academic status is largely determined by peer groups, rather than by an academic's department or university managers (Benabou \& Tirole, 2006).

Academics can be motivated by intrinsic rewards, as they desire to advance in their field and value peer recognition and core activities (Meyer \& Evans, 2003). Academics can be intrinsically motivated by several factors, such as autonomy and flexibility (Houston et al., 2006), the membership of a community of scholars (Bellamy et al., 2003), and a cooperatively-managed environment (Kwiek, 2015). This suggests that academics need to be 
supported to develop their key values and subject expertise if they are to develop as professionals. Only in this way can academics effectively achieve the goals and objectives of the university and enhance the quality of university education.

\section{Developing quality evaluation as a supportive mechanism}

University managers and policy-makers need to increase support to encourage the moral content of academic practice and to enhance academics' professionalism and their subject expertise. The outcomes-driven approach of quality evaluation values threshold standards. The focus on threshold standards encourages minimum standards (Stensaker \& Harvey, 2011) but does not promote excellence and continuous improvement. The focus on measuring quantifiable outcomes ignores that learning can be a process that is affected by various factors, such as student expectation, interest, habit, choice, commitment and capability to learn. This outcome-driven approach of quality evaluation, therefore, has not produced tangible improvements in student learning.

This paper proposes a refined quality evaluation system to be implemented at institutional and national level in order to rebuild trust in academic professionalism and to improve students' capability to learn. It is worth noting that current quality evaluation has not involved grassroot academic staff in the design and implementation of the system but detached them from this process by focusing on compliance and managerial control (Cheng, 2009). According to the motivational development theory proposed by Skinner et al. (2009), engagement is very important, as it affects immediate outcomes and leads to subsequent changes. The role of 
quality evaluation needs to shift from acting as a managerial tool for cost-effectiveness and external accountability to inspiring academics to pursue excellence and continuous improvement in teaching and learning. This will involve support from the government and the higher education sector to enact changes for long-term benefits.

The first key step is for the higher education sector to clarify whose responsibility it is for academic standards of quality evaluation. Research reveals that academics often relate quality to disciplinary values but the autonomy of academics and disciplines is largely absent from quality evaluation systems (Cheng, 2009; Houston, 2010). Current quality evaluation does not guarantee that student learning will be improved. Quality evaluation needs to respond to the issue of academics' responsibility for enacting and improving academic standards, move away from acting as a mechanism of state surveillance. A point of departure is that quality evaluation needs to be turned into a support mechanism to encourage individual academic's self-regulation of teaching and learning and to develop motivational forces for improvement. Higher education institutions need to take initiatives in promoting recognition and rewards activities in order to encourage academic staff to improve their teaching practice.

Studies indicate that recognition and rewards within the academic community are important motivational forces for academics. They take a wide range of forms, such as peer recognition and student expressions of appreciation (Houston et al., 2006; Radloff \& de la Harpe, 2007), financial rewards and pay-for-performance appraisal systems (Turk, 2008), and teaching excellence awards (Cheng, 2013). This paper argues in favour of using a peer-based method of recognition and reward as an option for refining quality evaluation. This method is 
different from the peer review adopted by current quality evaluation in that it would be based on academics' self-regulation and their peers' subject expertise to evaluate and to improve teaching and learning. It will avoid box-ticking exercises but focus on the provision of constructive feedback to support individual academics' professional development. This peer review would not add bureaucracy and extra expenditure. It can be easily operationalised and sustained on the basis of diversity, disciplinary natures and subject expertise. Diversity here refers to gender, ethnicity, sexual orientation and disability of academics (Deem, 2015). Subject expertise is key to this peer recognition and review because it encourages academics' responsibility in setting and monitoring academic standards for evaluation purposes. This does not involve the current institutional practice of providing a course of teacher training for academics but the engagement and leadership of experienced senior academics within the discipline to share teaching and learning good practice by linking to disciplinary norms and natures. In doing so, it could encourage the practice that academic staff lead the measurement of quality, increase the public's trust in academic professionalism and elevate academics' freedom to become innovative in teaching by developing disciplinary values.

A network approach involving key stakeholders in curriculum development could be used as another approach to move the administrative control away from academics in order to strengthen subject expertise in the disciplinary community. Networking here refers to strengthening subject expertise at institutional, national and international level. It provides a platform for academic staff to share and recognise good practice within their disciplines, with the support of professional and regulatory bodies. Sharing good practice of curriculum design 
and innovation would eventually lead to authentic collaboration among stakeholders and encourage a culture of improving teaching and learning. Figure 1 is a diagram of the proposed quality evaluation system that links peer recognition and review to a network approach to improve the disciplinary practice of teaching and learning.

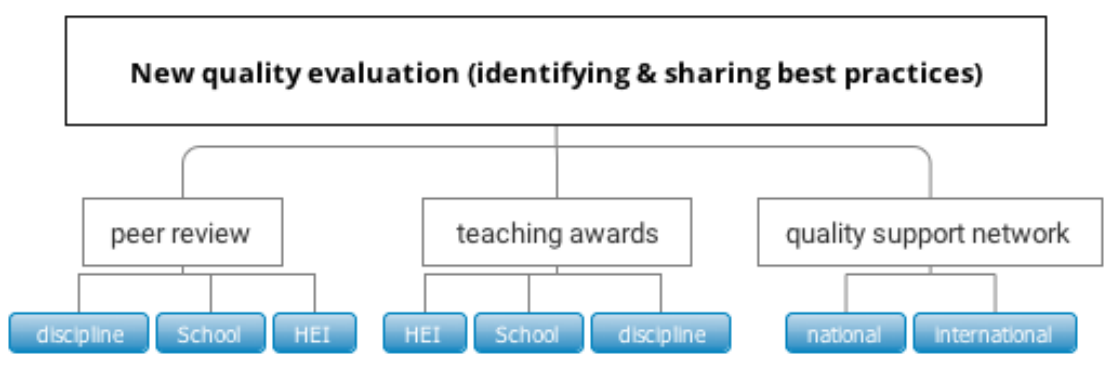

Figure 1: Quality evaluation system linking peer recognition and review to a network approach

\section{Conclusion}

To summarise, this paper critically reviews two most widely used definitions of quality in higher education: fitness for purpose and value for money. It argues for the importance of developing human factors in improving the quality of education and proposes a new understanding of quality as a virtue of professional practice, which could be achieved through strengthening academics' professionalism and improving students' capability to learn.

Considering that the outcome-driven approach of current quality evaluation does not promote excellence and continuous improvement, a refined quality evaluation system is proposed to work as a supportive mechanism to enhance academic staff's professionalism and students' capability to learn. 


\section{References}

Adams, R., 2006, A Theory of Virtue: Excellence in being for the good. (Oxford, Oxford University Press).

Al-Rubaish, A.M., Rahim, S.A., Abumadini, M.S. \& Wosornu, L., 2011, 'Academic job satisfaction questionnaire: construction and validation in Saudi Arabia', Journal of Family and Community Medicine, 18(1), pp. 1-7.

Anderson, G., 2006, 'Carving out time and space in the managerial university', Journal of Organizational Change Management, 19(5), pp. 578-592.

Arkoudis, S., Bexley, E., \& James, R., 2012, 'Addressing the Challenge of Maintaining the Australian Academic Workforce', Higher Education Forum, 3(9), pp. 89-103.

Bellamy, S., C. Morley, et al., 2003, 'Why business academics remain in Australian universities despite deteriorating working conditions and reduced job satisfaction: an intellectual puzzle. Journal of Higher Education Policy and Management', 25(1), pp. 13-28.

Benabou, R., \& Tirole, J., 2006, Identity, dignity, and taboos: Beliefs as assets. (Mimeo, Princeton University).

Biesta, G., 2015, 'What is education for? On good education, teacher judgement, and educational professionalism', European Journal of Education, 50(1), pp. 75-87.

Bolden, R. \& Petrov, G., 2008, Employer Engagement with Higher Education: A literature review, Report compiled for the South West Higher Level Skills Project on behalf of HERDA South West and HEFCE. 
Bowen, P. W., Rose, R. \& Pilkington, A., 2016, 'Perceived stress amongst university academics', American International Journal of Contemporary Research', 6(1), pp. 22-28.

Brown, R., 2014, What price quality enhancement? (York, Higher Education Academy). Department for Business Innovation and Skills (BIS), 2016, Success as a Knowledge Economy: Teaching Excellence, Social Mobility and Student Choice. Available at: https://www.gov.uk/government/uploads/system/uploads/attachment_data/file/523546/bis-16265-success-as-a-knowledge-economy-web.pdf

Capelleras, J., 2005, 'Attitudes of academic staff towards their job and organisation: An empirical assessment', Tertiary Education and Management, 11(2), pp. 147-166.

Cheng, M., 2009, 'Academics' professionalism and quality mechanisms: Challenges and tensions', Quality in Higher Education, 15 (3), pp. 193-205.

Cheng, M., 2011a, 'Transforming the learner' versus 'passing the exam': Understanding the gap between academic and student definitions of quality', Quality in Higher Education, 17(1), pp. 3-17.

Cheng, M., 2011b, 'The perceived impact of quality audit on the work of academics. Higher Education Research and Development', 30(2), pp. 179-191.

Cheng, M., 2012, 'Accountability and professionalism: Contradiction in terms?', Higher Education Research and Development, 31(6), pp. 1-11.

Cheng, M., 2013, 'Professionalising teaching identity and teaching 'excellence' schemes', in Gornall, et al. (Eds.). Academic working lives: Experience, practice and change (London, Bloomsbury). 
Cheng, M., et al., 2016, 'Student satisfaction and quality education: Testing the linkages', Higher Education Research and Development, 35(6), pp. 1153-1166.

Clayson, D. E., \& Haley, D. A., 2005, 'Marketing models in education: Students as customers, products, or partners', Marketing Education Review, 15(1), pp. 1-10.

Crosby, P. B., 1979, Quality is Free: The Art of Making Quality Certain. (New York, McGraw-Hill).

Deem, R., 2015, Critical commentary on Ray Land and George Gordon 'Teaching Excellence Initiatives: Modalities and Operational Factors. (York, Higher Education Academy).

Delucchi, M. \& Korgen, K., 2002, "We're the customer - we way the tuition": Student consumerism among undergraduate sociology majors', Teaching Sociology, 30 (1), pp. 100107.

Deming, W. E., 1986, Out of the Crisis. (MIT Press).

Department for Education and Skills (DES), 2003, The Future of Higher Education. (London, HESO).

Dill, D., 2001, 'The regulation of public research universities: changes in academic competition and implications for university autonomy and accountability', Higher Education Policy, 14(1), pp. 21-35.

DiPardo, A. \& Potter, C., 2004, 'Beyond cognition: A Vygotskian perspective on emotionality and teachers' professional lives', in A. Kozulin, B. Gindis, V.S. Ageyev and S.M. Miller. (Eds.) Vygotsky's Educational Theory in Cultural Context (Cambridge, Cambridge University Press). 
Drummond, H. (1992). The quality movement: What total quality management is really all about. London:

Kogan

Page. 
Eagle, L., \& Brennan, R., 2007, 'Are students customers? TQM and marketing perspectives', Quality Assurance in Education, 15(1), pp. 44-60.

Ehn, B. \& Löfgren, O., 2009, 'Routineso-made and unmade', in E, Shove., F, Trentman., R. (Eds.) Wilk Time, Consumption and everyday Life (Oxford, Berg).

Eraut, M., 1994, Developing Professional Knowledge and Competence. (London, Falmer).

Evetts, J., 2009, The management of professionalism: A contemporary paradox, in S. Gewirtz, P. Mahony, I. Hextall, \& A. Cribb. (Eds.), Changing Teacher Professionalism: International Trends, Challenges and Ways Forward (London, Routledge).

Evetts, J., 2013, 'Professionalism: Value and ideology', Current Sociology, 61(5/6), pp. 778796.

Freidson, E., 2001, Professionalism: The third logic. (Cambridge, Polity Press).

George, D., 2007, 'Market overreach: The student as custome', The Journal of SocioEconomics, 36(6), pp. 965-977.

Giroux, H., 2005, The Terror of Neoliberalism: Cultural Politics and the Promise of Democracy. (Boulder, CO, Paradigm Publishers).

Goodson, I., 1999, 'Towards a principled professionalism for teaching', Keynote address at the Conference on New Professionalism in Teaching, Chinese University of Hong Kong, Hong Kong.

Haggis, T., 2009, 'What have we been thinking of? A critical overview of 40 years of student learning research in higher education', Studies in Higher Education, 34(4), pp. 377-390. 
Harvey, L. \& Green, D., 1993, 'Defining quality', Assessment and Evaluation in Higher Education: An international journal, 18(1), pp. 9-34.

Harvey, L., Williams, J., 2010, 'Fifteen Years of Quality in Higher Education', Quality in Higher Education, 16(1), pp. 3-36.

Houston, D., 2008, 'Rethinking quality and improvement in higher education', Quality Assurance in Education, 16(1), pp. 61-79.

Houston, D., 2010, 'Achievements and consequences of two decades of quality assurance in higher education: a personal view from the edge', Quality in Higher Education, 16(2), pp. $177-80$.

Houston, D., L. H. Meyer, et al., 2006, 'Academic staff workloads and job satisfaction: expectations and values in academe', Journal of Higher Education Policy and Management, 28(1), pp. 17-30.

Tight, M., Mok, K, H., Huisman, J. \& Morphew, C., 2012, The Routledge International Handbook of Higher Education, $1^{\text {st }}$ edn. (London, Routledge).

Hutchins, D., 1992, Achieving Total Quality. (Cambridge, Director Books).

Kwiek, M., 2015, 'The unfading power of collegiality? University governance in Poland in a European comparative and quantitative perspective', International Journal of Educational Development, 43 , pp. $77-89$.

Johnson, M. P., 1973, 'Commitment: A Conceptual Structure and Empirical Application', The Sociological Quarterly, 14(3), pp. 395-406. 
Jones, G., 2010, 'Managing student expectations: The impact of top-up fees', Perspectives, 14 (2), pp. 44-48.

Larson, M. S., 1977, The Rise of Professionalism: A Sociological Analysis. (Berkeley, Calif, University of California Press).

Lomas, L., 2002, 'Does the development of mass education necessarily mean the end of quality?', Quality in Higher Education, 8(1), pp. 71-79.

Lusk, C. \& Fearful, A., 2015, 'Supporting students in higher education: results and recommendations following a paradigm shift within a Scottish Ancient', Studies in Higher Education, 40(6), pp. 1107-1127.

MacIntyre, A., 2007, After Virtue: A Study in Moral Theory, $3^{\text {rd }}$ edn. (Norte Dome, University of Norte Dome Press).

McAlpine, L., 2010, 'Fixed-term researchers in the social sciences: Passionate investment, yet marginalizing experiences', International Journal for Academic Development, 15(3), pp. 229240.

McMillan, J. J. \& Cheney, G., 1996, 'The student as consumer: The implications and limitations of a metaphor', Communication Education, 45(1), pp. 1-15.

Meyer, L. H. \& Evans, I. M., 2003, 'Motivating the professoriate: why sticks and carrots are only for donkeys', Higher Education Management and Policy, 15(3), pp. 151-167.

Mikkelsen, A., Ogard, T. \& Landsbergis, P., 2005, The effects of new dimensions of psychological job demands and job control on active learning and occupational health, Work \& Stress, 19(2), pp. 153-75. 
Molesworth, M., Nixon, E. \& Scullion, R., 2009, 'Having, being and higher education: the marketisation of the university and the transformation of the student into consumer', Teaching in Higher Education, 14(3), pp. 277-287.

Noordegraf, M., 2007, 'From 'pure' to 'hybrid' professionalism: Present-day professionalism in ambiguous public domains', Administration and Society, 39(6), pp. 761-85.

Nussbaum, M., 2000, ‘Women's capabilities and social justice', Journal of Human Development, 1(2), pp. 219-247.

Nussbaum, M., 2006, 'Education and democratic citizenship: Capabilities and quality education', Journal of Human Development, 7(3), pp. 385-395.

Radloff, A. \& de la Harpe, B., 2007, Institutional support for quality learning and teachingwhat's missing? Available at: http://www.auqa. edu.au/auqf/2007/proceedings/proceedings.pdf.

Redding, P., 2005, 'The evolving interpretations of customers in higher education: empowering the elusive', International Journal of Consumer Studies, 29 (5), pp. 409-417.

Ren, X. N., Caudle, D., 2016, 'Walking the tightrope between work and non-work life: strategies employed by British and Chinese academics and their implications', Studies in Higher Education, 41(4), pp. 599-618.

Sachs, J., 2003, The Activist Teaching Profession. (Buckingham, Open University Press).

Saltmarsh, J., 2016, 'A collaborative turn: Trends and directions in community engagement', in J, Sachs., L, Clark. (Eds). Learning Through Community Engagement (New York, Springer). 
Saunders, D., 2010, 'Neoliberal ideology and public higher education in the United States', Journal for Critical Education Policy Studies, 8, pp. 41-77.

Saunders, D.B., 2011, 'Students as customers: The influence of neoliberal ideology and freemarket logic on entering first-year college students'. Open access dissertations. Paper 377. Available at: http://scholarworks.umass.edu/open_access_dissertations/377

Saunders, D. B. \& Ramirez, G. B., 2016, 'Resisting the neoliberalization of higher education: A challenge to commonsensical understandings of commodities and consumption', Cultural Studies. Available

at:

http://csc.sagepub.com/content/early/2016/09/20/1532708616669529.full.pdf+html

Schwarz, S. \& Westerheijden, D., 2004, Accreditation and Evaluation in the European Higher Education Area. (Dordrecht, Kluwer Academic Publishers).

Sen, A. K., 1992, Inequality Reexamined. (Oxford, Oxford University Press).

Sen, A., 1999, Development as Freedom. (Oxford, Oxord University Press).

Sharrock, G., 2000, 'Why students are not (Just) customers (and other reflections on Life After George)', Journal of Higher Education Policy and Management, 22(2), PP. 149-165.

Sideridis, G. D., 2001, The causal role of goal importance for the explanation of student study behaviour: Cross-validation with multiple samples, Educational Psychology: An International Journal of Experimental Educational Psychology, 21(3), pp. 277-298.

Skinner, E. A., Kindermann, T. A., Connell, J. P. \& Wellborn, J. G., 2009, ‘Engagement as an organizational construct in the dynamics of motivational development', in K. Wentzel, \& A. Wigfield. (Eds.). Handbook of Motivation in School (Malwah, NJ, Erlbaum). 
Skolnik, M. L., 2010, 'Quality Assurance in Higher Education as a Political Process', Higher Education Management and Policy, 22 (1), pp. 67-86.

Stensaker, B. \& Harvey, L., 2011, Accountability in Higher Education: Global Perspectives on Trust and Power. (New York, Routledge).

Tipples, R., Krivokapic-Skoko, B. \& O'Neill, G., 2007, University academics' psychological contracts in Australia and New Zealand, New Zealand Journal of Employment Relations, 32(2), pp. 32-52.

Titus, J. J., 2008, 'Student ratings in a consumerist academy: Leveraging pedagogical control and authority', Sociological Perspectives, 51(2), pp. 397-422.

Tomlinson, M., 2016, 'Student perceptions of themselves as 'consumers' of higher education', British Journal of Sociology of Education, Available at: http://www.tandfonline.com/doi/abs/10.1080/01425692.2015.1113856

Turk, K., 2008, 'Performance appraisal and the compensation of academic staff in the university of Tartu,' Baltic Journal of Management, 3(1), pp. 40-54.

Watty, K., 2003, When will academics learn about quality, Quality in Higher Education, 9(3), pp. 213-21.

Westerheijden, D., Hulpiau, V. \& Waetens, K., 2007, 'From design and implementation to impact of quality assurance: An overview of some studies into what impacts improvements', Tertiary Education and Management, 13(4), pp. 295-312.

Wicks, A, M., Roethlein, C, J., 2009, 'A satisfaction-based definition of quality', The Journal of Business and Economic Studies, 15(1), pp. 82-97. 
Williams, J., 2012, Consuming Higher Education: Why Learning can't be Bought. (London, Bloomsbury).

Winch, C. \& Foreman-Peck, L., 2005, 'What do we mean by teachers' professionalism and pofessional knowledge? How useful are these concepts?', Paper presented at the Changing teachers' roles, identities and professionalism seminar series, King's College, London.

Winston, G. C., 1999, 'Subsidies, hierarchy and peers: The awkward economics of higher education', The Journal of Economic Perspectives, 13(1), pp. 13-36.

Winter, R., Taylor, T. \& Sarros, J., 2000, 'Trouble at mill: Quality of academic worklife issues within a comprehensive Australian university', Studies in Higher Education, 25 (3), pp. 279-294.

Woodhouse, D., 1996, 'Quality assurance: international trends, pre-occupations and features', Assessment and Evaluation in Higher Education, 21(4), pp. 347-356. 